duced in the year-book for 1944. Observations and records of solar activity during 1944 have continued, and the results, together with those made at the observatories of Valencia and Cartuja, have been sent to the International Bureau at Zurich. Time signals have been carried out, and photographs of comets and planets, occultations of stars by the moon and other notable phenomena have been included in the programme. Boletin Astronómico, 2, No. 10, contains the results of observations of sunspots and prominences in 1938 and the positions of a number of comets observed in 1941 and 1942, while Bol. Ast., 3, No. 1 contains the results of solar observations made in 1939 and 1940, including also those made during the latter year at Valencia. Repairs were started in the Observatory, those to the astrographic pavilion being completed, and the installation of the instrument and the new cupola to house it will allow the renewal of observations. At the end of the year-book there is an interesting section containing 72 pages with the title "El Sistema Galáctico", by José María Torroja Menéndez. This provides a very useful summary of our knowledge of the galaxy.

\section{Belgian Scientific Delegates in Britain}

A THIRD group of Belgian professors representing the Belgian Fondation Universitaire is now visiting Britain for a fortnight at the invitation of the British Council. They are visiting universities or research institutions in London, Reading, Oxford, Cambridge, Newcastle, Aberdeen, Edinburgh, Liverpool and Greenwich, and the I.C.I. works at Billingham. The delegates are: Prof. F. Van den Dungen, professor of analytical mechanics, University of Brussels ; Prof. A. Michotte van den Berck, professor of experimentary psychology, University of Louvain; Prof. A. Gratia, professor of bacteriology, University of Liège; Prof. J. A. H. Rodhain, director of the Institute of Tropical Medicine, Antwerp; Prof. E. J. M. P. Mertens, professor of industrial chemistry, University of Louvain.

\section{Cambridge Summer School in X-Ray}

\section{Crystallography}

A SUMMer school in X-ray crystallography will be held again this year in the Department of Mineralogy and Petrology, and in the Cavendish Laboratory, Cambridge, during the two weeks September 3-14. The school is conceived as a means of providing an introduction to the fundamental theory, methods and techniques of X-ray diffraction, so that those whose researches, whether in the universities or in industry, lie in the field of physics, chemistry, metallurgy, mineralogy or biology may be able to recognize in their own work the types of problem to which these methods may with advantage be applied. The greater part of the course will be devoted to practical work on the interpretation of the various types of X-ray photograph. For the last two days, however, alternative lectures and demonstrations will be offered in two sections. One section will include further steps, theoretical and practical, in the study of crystal structures, while in the other some applications of the earlier work of the course to metallurgical problems will be studied. A detailed syllabus and form of application for admission may be obtained from Mr. G. F. Hickson, secretary of the Board of Extra-Mural Studies, Stuart House, Cambridge, to whom the completed application form should be returned not later than June 23, 1945.

\section{Announcements}

THE following appointments in the Colonial Services have been made: W. J. Kinghorn, to be director of agriculture, Bermuda; Miss B. Y. Campbell, to be nutrition officer, Trinidad; T. A. Russell, director of agriculture, Bermuda, to be agricultural officer, Nigeria ; N. M. Wight, agricultural officer, Tanganyika, to be senior agricultural officer, Jamaica.

Ar the anniversary meeting of the Linnean Society of London held on May 24, the following were elected officers for the year 1945-46: President, Mr. A. D. Cotton; Treasurer, Colonel F. C. Stern; Secretaries, Dr. B. Barnes (botany) and Dr. Malcolm A. Smith (zoology); New Members of Council, Mr. A. H. G. Alston, Prof. T. A. Bennet-Clark, Dr. F. C. Fraser, Dr. H. S. Holden and Dr. S. M. Manton.

AT the annual general meeting of the Physical Society on May 23 the following were elected or reelected for 1945-46: President, Prof. D. Brunt; Vice-Presidents, Sir Edward Appleton, Prof. S. Chapman, Prof. H. T. Flint, Prof. N. F. Mott ; Hon. Secretaries, Mr. J. H. Awbery (Papers), Dr. W. Jevons (Business); Hon. Foreign Secretary, Prof. E. N. da C. Andrade; Hon. Treasurer, Dr. C. C. Paterson; Hon. Librarian, Prof. L. C. Martin; Council, Prof. J. D. Bernal, Dr. B. Chalmers, Dr. C. H. Collie, Mr. E. R. Davies, Prof. G. I. Finch, Dr. W. B. Mann, Mr. A. J. Philpot, Dr. D. Roaf, Prof. H. R. Robinson, Dr. H. Shaw, Dr. W. S. Stiles, Dr. W. D. Wright. The officers of the Colour Group for 1945-46 are : Chairman, Dr. R. K. Schofield; Secretary, Dr. W. D. Wright; and of the Optical Group, Chairman, Inst. Capt. T. Y. Baker; Secretary, Mr. E. W. H. Selwyn.

AT the annual general meeting of the Illuminating Engineering Society held on May 15 the following were elected officers for the forthcoming session: President, Mr. H. C. Weston; Vice-Presidents, Mr. Howard Long, Mr. H. E. Chasteney and Mr. J. M. Waldram; Hon. Treasurer, Mr. N. V. Everton; Hon. Secretary, Mr. J. S. Dow ; Members of Council, Mr. J. N. Aldington, Mr. M. G. Bennett, Dr. W. M. Hampton, Mr. A. G. Higgins, Mr. J. S. Preston, Mr. A. J. Pashler, Mr. E. B. Sawyer, Dr. W. S. Stiles and Dr. W. D. Wright.

AT the meeting of the Board of the Finney-Howell Research Foundation, Inc., on March 2, fellowships were renewed for the third year for Dr. Nelicia Maier; for the second year for Drs. Muriel Virginia Bradley and Margaret Aston Kelsall; and a new fellowship awarded to Dr. Elizabeth Cavert Miller, to work at the University of Wisconsin. Applications for fellow. ships for 1946 must be made to the Foundation, Medical and Chirurgical Faculty Building, 1211 Cathedral Street, Baltimore, Md., U.S.A., before December 1945.

The Leeds Branch of the Association of Scientific Workers will hold an open conference on "Science and Education" at the Philosophical Hall, City Museum, Leeds, on June 9, at 2.30 p.m. It is hoped to discuss the teaching of scientific method in elementary education, the comparative value of science and the humanities in general education, and curricula for specialist technicians. Sir Robert Watson-Watt will open the discussion and Dr. W. T. Astbury will preside. Tickets of admission (price 18 .) can be obtained from the honorary secretary of the Leeds Branch of the Association of Scientific Workers, 95 Holywell Lane, Glasshoughton, Castleford. 